2019

\title{
Tunisian terrorist fighters: a grassroots perspective
}

Imene Ajala

University of Wollongong, imene@uow.edu.au

\section{Publication Details}

Ajala, I. 2019, 'Tunisian terrorist fighters: a grassroots perspective', Behavioral Sciences of Terrorism and Political Aggression, vol. 11, no. 2, pp. 178-190.

Research Online is the open access institutional repository for the University of Wollongong. For further information contact the UOW Library: research-pubs@uow.edu.au 


\title{
Tunisian Terrorist Fighters: A Grassroots Perspective
}

\author{
Imène Ajala*
}

${ }^{a}$ Arts and Humanities, University of Wollongong in Dubai, Dubai, United Arab Emirates

University of Wollongong in Dubai, Knowledge Park,

PO Box 20183, Dubai, United Arab Emirates

AjalaImene@uowdubai.ac.ae

+97142781950 


\title{
Tunisian Terrorist Fighters: A Grassroots Perspective
}

\author{
In a hectic consolidation phase plagued by security, economic and social \\ challenges, Tunisia has stood out as the biggest sender of foreign terrorist fighters \\ to the so-called Islamic State. How do grassroots forces frame the issue in the \\ context of the democratic transition and post-revolutionary consolidating phase? \\ In order to address this question, this article builds on fieldwork visits to Tunisia \\ (including observation of the parliamentary elections in 2014 and background \\ talks) and relies on a set of semi-structured interviews conducted from 2014 to \\ 2017 with Tunisian civil society activists, students and young people, understood \\ as voices representing grassroots. Though viewpoints from the grassroots agree \\ on economic and social grievances as a motivating factor for Tunisian terrorist \\ fighters, more emphasis is drawn to the ideological void filled in by the Salafi \\ discourse after the Arab Spring and the need to replace the Tunisian \\ understanding of Islam related to the Middle Way (el Wasatiyyah) in the political \\ debate.
}

Keywords: Tunisia; Islam; foreign fighter; terrorism; grassroots: middle-way

\section{Introduction}

In the tumultuous aftermaths of the Arab Spring, the only country which appears to have engaged a process of democratization is precisely where everything started: Tunisia. However, several political, social and security challenges threaten the process (Hmed 2016). Tunisia has particularly stood out as the first sender of foreign fighters to the so-called Islamic State in Syria and Iraq, puzzling observers (Malka and Balboni 2016: Watanabe and Merz 2017).

Drawing on the findings of the African Barometer highlighting that the perceptions of extremist threats were the highest in Tunisia and Egypt (Bentley, Lekalake and Buchanan-Clarke 2016), this analysis seeks to add to these quantitative findings a qualitative perspective to better characterize the perceptions of these threats, namely, the reasons perceived behind radicalization and the best way to address them. 
What are some of the grassroots perspectives on Tunisian terrorist fighters in the context of the democratic transition and post-revolutionary consolidating phase? In order to address this question, this article builds on fieldwork visits to Tunisia (including observation of the parliamentary elections in 2014 and background talks) and eleven semi-structured interviews conducted from 2014 to 2017 with civil society activists, students and young citizens that we subsume under the term of 'grassroots', without having the pretension to represent the whole spectrum of Tunisian society. The first interviews were conducted in 2014. The last set of interviews was conducted in 2017 with one follow-up interview with an informant already interviewed in 2014. Some of them took place face-to-face and others by Skype. In terms of situatedness, and in order to enhance the precision of data collection, interviews were individually conducted in the Tunisian dialect and thus, in a conversational style. Civil society organizations were first used as an entry point: people active in institutionalized civil society organizations were approached and accounted for judgment sampling due to their exposure and subsequent knowledge of the post-transitional stage. In a second stage, a combination of snowball and opportunities sampling allowed access to young people, mostly students in order to broaden the consideration to "grassroots", and not simply, to civil society organizations.

As highlighted by Bentley, Lekalake and Buchanan-Clarke, surveying grassroots perspectives can add "community-level perceptions that could be useful as counterextremism policies are developed and refined" (Bentley, Lekalake and BuchananClarke 2016, 1). In fact, grassroots' perspectives of the level of terrorist threat do not necessarily match the objective events: Bentley, Lekalake and Buchanan-Clarke note that: 
Tunisia experienced far fewer terror attacks in 2014 (23) than Egypt (346) and Sudan (157), yet Tunisians were more likely to view ISIL and AQIM as a threat than were Egyptians and Sudanese. Higher levels of perceived threat in Tunisia may reflect factors that are not captured in Global Terrorism Data, such as local intimidation through forced recruitment, kidnappings, and the return of foreign fighters. Citizen perceptions, in this case, can be useful for a fuller understanding of the security situation, which may not be readily assessable through incident data alone (Bentley, Lekalake and Buchanan-Clarke 2016, 6).

This article has two sections. As one of the actors understood as part of the grassroots is civil society, the first section retraces the background of the Tunisian transitional context because it directly has an impact on civil society and the roles it can adopt in a post-revolutionary context. The second section gives an overview on the global issue of foreign terrorist fighters, its local characteristics for the case of Tunisia, the motivations usually advanced in the literature and the challenges implied by their return, while putting forward what is considered here as grassroots perspectives, namely, the voices of civil society activists, students and young Tunisians interviewed for this article on two essential elements: the motives perceived behind radicalization and the appeal of the so-called Islamic State as well as the means to counter-extremist narratives.

\section{Tunisian Civil Society in Transition}

\section{From Revolution to Transition}

Mohammed Bouazizi, a young street vendor set himself on fire on 17 December 2010 after being denied a vendor permit by local authorities. This unleashed several popular protests starting first in Sidi Bouzid before spreading to the country and to the region, a revolutionary wave known as the Arab Spring. While Ben Ali promised to crush demonstrations, the Chief of the Tunisian Armed Forces, Rachid Ammar assured 
that the Army would not shoot unarmed protesters. On 14 January 2011, Prime Minister Mohamed Ghannouchi announced an interim government, following the escape of the former President Ben Ali to Saudi Arabia, putting an end to twenty-three years of autocratic rule. Fouad Mebazaa, the President of the Assembly, became president and replaced Mohammed Ghannouchi with Béji Caid Essebsi after several protests against former collaborators of Ben Ali. Elections were held in October 2011 in order to establish a National Constituent Assembly charged with drafting and adopting a new constitution. Enhadha clearly stood out as a contender, benefiting from an aura of early opponent to Ben Ali's regime (Fortier 2015). The outcome of the elections in October 2011 lead to the formation of a coalition government with two other secular parties, the Rally for the Republic Party (CPR) and Ettakatol party, forcing compromise (Zisenwine 2016). Moncef Marzouki, leader of the CPR, was elected interim President by the Assembly in December 2011. However, the grace period quickly ended as the party quickly seemed overwhelmed by mounting economic and social challenges and rising expectations, while Islamists were being equally contested in Egypt (Zisenwine 2016).

The transitional process was paralyzed by the assassination of two leftist prominent figures of the secular opposition: Chokri Belaid on 6 February 2013 and Mohamed Brahmi on 25 July 2013. A series of terrorist attacks perpetrated by al-Qaeda in the Islamic Maghreb (AQMI) against security forces further contributed to tensions. In October 2013, Enhadha party agreed to step aside in favour of a non-partisan, technocratic government to pave the way for elections in 2014. The technocratic government led by Mehdi Jomma helped avert the crisis (Zisenwine 2016).

Contrary to the vibrant political landscape of the October 2011 elections, a general apathy and lack of interest characterized the elections of October 2014, especially from the youth (Zisenwine 2016). The presidential elections consecrated the 
victory of Nidaa Tounes and Béji Caid Essebsi but Nidaa Tounes, the new victor, also needed to include Enhadha in the government as it remains a central force political force (Zisenwine 2016).

On 24 January 2014, in a historical moment, the Constituent Assembly finally adopted the new Constitution. The constitutional process was probably the best illustration of the degree of inclusiveness of civil society (Ajala, Paffenholz et al. 2013: Fortier 2015). Despite delays, the process successfully relied on commissions representing the different political sensitivities and regular meetings with citizens in the different wilayas, and abroad with the diaspora. The constitution reflects a delicate balance between the Muslim, Arab and African identities of the country and bears the mark of the Tunisian School of Reformed Muslim Thought represented by Tahar Ben Achour (Laabidi 2014). However, and in order to gather a maximum of support, the constitution necessarily suffers from a part of vagueness and risky compromises (Kelly 2014). Serious challenges continue to lie ahead regarding its implementation, including the necessity to engage more actively civil society (Laabidi 2014). There has been mounting social contestation, especially from internal regions, aggravated by a lack of trust in political leadership and resulting into a "trend for rioting" (Kerrou 2017).

\section{Civil Society in Transition}

Transitions are understood here as long-term complex societal processes of change involving different dimensions of transitions from authoritarian to more participatory forms of governance often accompanied by violence (Schmitter and O’Donnell 1986). Change is not as a linear process as it is characterized by regression, stagnation and/or the existence of hybrid forms of governance and societal arrangements where different phases of transition can take place in parallel. Transitions imply complex social, political and economic transformations on a long term. These 
transformations entail instability and can be prone to violence and/or state fragility. This section aims at defining civil society and its roles in the Tunisian transition not only because civil society organizations are used as part of the grassroots but also because the transition allows for changes in the political opportunity structure that can facilitate radicalization as we shall see. It is thus necessary to account for the potential role of civil society in disrupting this process facilitating radicalization before considering the issue of terrorist fighters.

Civil society is comprised out of a set of diverse actors from professional associations, faith-based organizations, professional service delivery or human rights advocacy NGOs as well as traditional groupings or youth clubs that can take up various roles in different phases and sub-phases of transition. Any comprehensive attempt to understand the role of civil society in transitions needs to address the heterogeneous notion, different discourses and practices of the concept in various historical and geographical contexts as well as in different academic traditions (Paffenholz 2010).

Concerning civil society in the Middle East and North Africa before the Arab Spring, the literature generally emphasized the weakness of civil society to counter strong and authoritarian regimes (Sadowski 1993, 15). Nevertheless, Norton had already noted a gradual opening of political space under some authoritarian states due to increasing pressure from citizens (Norton 1995, 4-8). Vallianotes similarly argues that a grassroots movement was actually in the making in the years preceding the "Arab Spring" (Vallianatos 2013, 6).

Civil society adopts different roles in the different subphases of transitions or the liberalisation, institutionalisation and consolidation phases (Schmitter and O'Donnell 1986). Paffenholz and Spurk suggest a model based on seven functions (protection, monitoring, advocacy, socialisation, social cohesion, facilitation, service delivery) as 
part of a comprehensive framework for the analysis of civil society in transitions (Paffenholz and Spurk 2010). Civil society actors perform a variety of social and political functions with specific impacts on distinct subphases of transitions. Additionally, the impact of these functions is strongly influenced by the context in which these different civil society actors are operating. Civil society facilitates democratic consolidation processes by adopting different roles: agenda-setter, civic education of the people, a source for alternative constellations of power (Behr \& Sittonen 2013,9$)$. The possibility of civil society acting in these roles depends on the level of repression, pluralism and the mode of transition (Behr \& Sittonen 2013, 9).

According to Behr and Sittonen, "the Arab Spring revolutions provided a sudden boost to civil society activism across the Middle East" (Behr \& Sittonen 2013, 14). The Arab Spring saw the emergence of "a new model for the genre: no leader, no ideological program and no organized popular bases, rather, an accumulated popular demand for change" (Sakbani 2011, 144). They were characterized by their unexpectedness, their spontaneity, lack of leadership and organization (Volpi, 2012, 3: Weyland 2012, 924). They also revealed the inefficiency of traditional tools of mobilization in the authoritarian contexts of the region. Young Arabs took the streets disregarding the "traditional ineffective civic forms of organizing such as political parties and the so-called non-governmental organizations" (Ziad Abdel Samad, quoted in Halaseh 2013, 258). The challenges faced by civil society organizations undermined their credibility as legitimate representatives so young educated Arabs acted on their own. The number of civil society groups quickly increased in the aftermath of the Revolution in Tunisia (Fortier 2015). However, after the enthusiasm of the revolutionary period, it was very difficult for activists to maintain the momentum especially in the context of growing divisions (Weyland 2012, 924), the first one being 
the divide between religious and secular forces (Behr \& Sittonen 2013, 10). This big line of division between Secular and Islamist constellations should not blind us from the deep internal divisions within each side. The strong divisions between liberal groups are in fact well documented (Aliboni 2011, 8). The Arab Spring also has had effects on Islamism as it showed the heterogeneity of the Islamist scene, the use of Islamist informal networks especially with social media, the change in discourse (less focused on the religious state than on good governance) and the emergence of new clashes within this sphere (Al-Anani 2012; Roy 2012).

Despite that, the Tunisian civil society was able to act as a vocal agenda-setter (Behr 2013, 10). This was strongly confirmed by one interviewee, Riadh, a project manager in an association for civic education training ${ }^{1}$. He considered that the transitional process was well-engaged despite its numerous flaws with the highest achievements being a fairer division of power at the top of the state, a decentralization of power in order to engage citizens locally, a vibrant civil society with the proliferation of several associations estimated at around 18000, and finally, the establishment of instances of regulation to ensure fairness such as the High Council for the Realization of the Goals of the Revolution, Political Reforms, and Democratic Transition favoring the cooperation between civil society and the government. From Riadh's perspective, the biggest issue seems to be the lack of popular participation. Riadh explained for example, how the revolution created high and unrealistic expectations which of course could not be met in such a short amount of time. This concretely translated in the lack of continuation of the associations created after the revolution and a general disaffection and disengagement from the political life. Riadh concluded that in this consolidating phase, the most important function of civil society was monitoring. An enhanced and collaborative partnership between the state and civil society was often suggested by 
other informants as a crucial element for a better contribution of civil society to transition processes. All interviewees agreed on the crucial role of civil society in monitoring the transitory phase to ensure a non-return to dictatorship. Out of the seven functions identified by Paffenholz and Spurk, the monitoring function is singled out as the most important in the current phase of consolidation, especially in an unstable security context that can lead to State moves reminiscent of the authoritarian Ben Ali's regime. Monitoring by civil society is rendered even more complex given the issue of Tunisian Terrorist Fighters and their return: how do voices from civil society, and from other grassroots' forces such as students or young people frame the issue of radicalization?

\section{Views from grassroots on radicalization and counter-extremism}

A number of foreign fighters coming from all corners of the globe, have been joining violent Islamist groups in Iraq and Syria; first and foremost, the so-called Islamic State. The Islamic State (IS) or Daesh can be considered as a salafi jihadist and extremist movement which, from its perspective, fights for Sunni Muslims suffering from several injustices (Bunzel 2015; Petré 2015). Daesh has acted as a magnet for candidates to jihad (Bakker and de Leede 2015). The United Nations speak of 30,000 foreign fighters coming from more than 100 countries (Security Council CounterTerrorism Committee ND). Contrary to the widespread assumption that the recruitment of foreign fighters is a new problem, the phenomenon has as a matter of fact emerged in numerous civil conflicts such as the Spanish Civil War, the Afghan struggle against the Soviets, the Bosnian conflict in the 1990's, and the Chechnya armed conflicts, to name a few (Hegghammer 2010). The Geneva Academy of International Humanitarian Law and Human Rights defines a foreign fighter as an "individual who leaves his or her 
country of origin or habitual residence to join a non state armed group in an armed conflict abroad and who is primarily motivated by ideology, religion and/or kinship" (Geneva Academy 2014, 6). However, new methods along with the Internet have increased the speed of radicalization and facilitated the whole process, provoking a noticeable change of scale (Carter, Maher and Neumann 2014; Saltman and Winter 2014). As an example, one of the interviewees, Meriem, who was a student in Southern Tunisia in 2014, explained her surprise to see the radical shift affecting some of her former fellow students, noting the rapidity of the radicalization and attributing it to intense activity on the Net. She explained how she perceived this shift through social media:

I had them on Facebook...And from one day to another...you see the change... Only posting religious stuff, some of the guys growing a beard, and you hear here and there that this fellow or that one has vanished...presumably to Syria ${ }^{2}$.

'New spiritual authorities' operate indeed on the Internet and act as inspirational figures, representing the emergence of a new style of virtual preacher without borders. These disseminators are not even necessarily in the field, but they act on their own initiative for the cause of Daesh (Carter, Maher and Neumann 2014). Twitter for instance is a major tool for disseminators (Klausen 2015). Profiles are developed to share updates and a range of hashtags are mobilized to share media content and serve propaganda. Facebook accounts give the possibility to share all the aspects of the jihadi life in Syria. Even humor and the codes of geek and pop culture are used in the process, in order to normalize the status of these fighters and thus attract even more potential candidates, as the tech-savvy generation is the main target of Daesh (Atwan 2015, 20). 
Estimates by the Soufan Group, the United Nations or the International Centre for the Study of Radicalisation all place Tunisia as the top exporter of foreign fighters (Sayah 2017; Watanabe and Merz 2017). The instability of the post-revolutionary phase implies a highly contested political opportunity structure, occasionally contracting but also expanding spaces for a renewed political expression (Fortier 2015). The spaces of free expression that opened up after the revolution were quickly and successfully occupied by the Salafi discourse which grew after the uprisings, especially for da'wa ${ }^{3}$ and encouragement to jihad against Bachar al-Assad (Malka and Balboni 2016; Watanabe and Merz). Ansar al-Sharia, which was officially classified as a terrorist group by the Tunisian government only in August 2013, has been especially successful in exploiting the political opportunities and the weaknesses opened by the transition to socialize youth in radicalization in a process of re-territorialisation and simultaneously, de-territorialisation (Petré 2015; Sayah 2017). Indeed, while a number of attacks have been conducted within the country such as the attacks at the Bardo Museum and in Sousse in 2015, as well as the attempt at taking control of Ben Guerdane in March 2016, Tunisian-born assailants were also involved in the two deadly attacks taking place Nice in France on July 14, 2016 and in Berlin on December 19, in 2016. The regional context also exacerbates the volatility of security as Libya has been used as a ground for training (OHCHR 2015). The Tunisian Centre for Research and Studies on Terrorism was able to analyse 384 files of judicial proceedings relating to 2224 presumed terrorists available from end of 2011 to end of 2015 . They reveal that Libya plays a major role as a hub for training as $70 \%$ of the presumed terrorists went through training camps in Libya (Tunisian Centre for Research and Studies on Terrorism 2016). 
The United Nations Working Group on the use of mercenaries has called on the Tunisian government to adopt strong measures to stop the flow of Tunisian fighters (OHCHR 2015). Now, with the Islamic State losing ground at least territorially (The Guardian, 7 September 2016) and on the Net as propaganda is much less active (Milton 2016), it is the return of these fighters that has turned into a pressing issue. After acquiring fighting skills, possibly more ideological arguments and benefiting from a new legitimacy of 'jihadi veteran', returnees can act as inspirational figures for candidates to jihad (Baker, Paulussen and Entenmann 2014; Bakker and de Leede 2015). This can also lead to the establishment of sleeper cells which can be ready to strike at any times. The eternal dilemma between security and freedom is acutely raised when considering how to deal with returnees. Liberal democracies have to walk a fine line between these two imperatives. In fact, the UN resolution 2178 (UN Security Council 2014) calls for states to 'ensure that any measures taken to counter terrorism [must] comply with all their obligations under international law, in particular international human rights law.' Jacinto recalls that 'The resolution refers states to the findings of the Global Counterterrorism Forum, a multinational initiative launched in 2011 by then U.S. Secretary of State Hillary Clinton, which called on governments to "use evidence-based, individual-level risk assessment frameworks for returnees, evaluate their condition and establish appropriate engagement approaches accordingly"' (Jacinto 2014). Finding this balance in a transitional context proves even more challenging.

800 fighters at least have returned to Tunisia according to estimates from the Ministry of Interior (Argoubi 2016). Prime Minister Youssef Chahed assured that "Those who come back will be arrested immediately after their arrival on Tunisian soil and will be judged under the anti-terrorism law" adopted in 2015 (Argoubi 2016). 
Several demonstrations took place in January 2017 to protest against the return of these fighters, reflecting the sensitivity of the issue. Already in 2013 , while $81 \%$ of Tunisian respondents indicated that they were worried about not finding a job, $91 \%$ indicated being worried about a terrorist attack (World Values Survey 2013), a fear currently heightened by the prospect of the returnees.

The Tunisian state appears to navigate between the temptation of former methods and the post-revolutionary requirements in terms of new spaces for freedom, complicating the institutional environment for civil society groups. Tunisia's antiterrorism law was passed in the wake of the attacks at the Bardo museum in Tunis and the attack on a beach in the Tunisian city of Sousse (Argoubi 2016). The Bill on "Repression of Attacks against Armed Forces" adopted in April 2015 was criticized by NGOs but also Tunisian parties and unions for threatening the freedom of expression and not complying with international law (Human Rights Watch 2015; International Commission of Jurists 2015; Zelin 2015). The increasing monitoring of mosques and the closing of various charities and madrasas was also denounced by international human rights NGOs while the government argued that this was required given the terrorist threat. This general hardening of the governmental position, leading to cases of mistreatment in detention, torture and mass arrests also became one of the factors fuelling radicalization (Watanabe and Merz 2017, 139).

There is actually no consensus on the motives behind the radicalization of foreign terrorist fighters but a myriad of different factors, from psychology to economic, social, ideological and political factors. The United Nations Working Group on the use of mercenaries lists 'religious and political ideologies, financial gains, economic and social conditions, sense of purpose, and sense of belonging' as motivational factors (OHCHR 2015). Across North Africa, widespread poverty, religious beliefs, 
unemployment and lack of opportunities are put forward by citizens of the region as the main motivations behind joining Daesh (Bentley, Lekalake and Buchanan-Clarke 2016, 2). Indeed, poverty alone does not explain extremism (Krueger 2007). The lack of civil liberties, bad governance, corruption, oppression or social grievances have been advanced as factors potentially leading someone to turn to extremism (Krueger 2003: Krueger \& Maleckova, 2003: Bueno de Mesquita 2005: Macdonald and Waggoner 2018). In any case, monocausality should be avoided when accounting for the factors leading to extremism. In the specific case of Tunisia, it seems expectations' management seems a prevalent factor: Macdonald and Waggoner point to the “expectations-versus-reality gap" between Tunisians' aspirations and the harsh realities of the slow progress of democracy, prevalent corruption and high unemployment (Macdonald and Waggoner 2018). It was previously noted that one of the interviewees, Riadh, precisely attributed the dwindling popular participation in elections to the creation of these unmet high expectations. In this context, the rhetoric of the Islamic State can be viewed as providing a sense of purpose and new opportunities (Macdonald and Waggoner 2018).

The Tunisian Centre for Research and Studies on Terrorism analysis of 384 files of judicial proceedings reveals that $96 \%$ of the presumed terrorists are male. $40 \%$ of the presumed terrorists have received higher education though only $12 \%$ have effectively graduated from University. Still, these figures show the economic and social heterogeneity of the backgrounds, dismissing the prevalence of economic and social deprivation as the number one motivation (Tunisian Centre for Research and Studies on Terrorism 2016). This confirms the United Nations Working Group observation on the use of mercenaries reporting that 'some of these young persons come from poor socioeconomic yet there are also some who are from middle class and wealthier parts of 
society' (OHCHR 2015). One of the interviewees, $\mathrm{Saber}^{4}$, a young University graduate saw one of his friends leave to and die in Syria. Saber shared a similar view when it comes to the limits of deprivation as a factor. He emphasized the economic and social situation of his friend to insist that a purely economic reading of the crisis is misleading ${ }^{5}$. His friend was a university graduate and occupied a manager position in a call center. Saber insisted on the perfect fluency of his friend in French to emphasize that he was 'a very smart guy'. He suddenly left for Syria in 2014 but news of his death quickly reached the neighbourhood:

He spoke French so well... without an accent. He was a manager in a call centre and he was managing a team. Then, in the blink of an eye, he left. We heard he died in Syria something like three weeks after he left.

Similarly, Houda, one of the interviewees who is active in an association working on Tunisian families, pointed to the lack of economic and social opportunities first but then insisted that the key to counter radicalization lies in education ${ }^{6}$. She more explicitly emphasized the role of families and the lack of transmission of values, which seems to have been exacerbated by a crisis of identities. Lost between a form of cultural westernization and a conservative society, young Tunisians become more vulnerable to arguments linked to religious purity.

Riadh also started observing that unemployment was indeed an aggravating factor of youth disenchantment. He identified radicalization as a reaction to economic and social conditions whereby youth felt abandoned by the state. The volatile and fragile process of transition, the high rates of unemployment and high but unmet expectations brought by the Revolution (Fortier 2015) thus provide fertile ground for Daesh, viewed as a provider of new opportunities and projects to this disillusioned youth. However, from Riadh's perspective, the key for countering radicalization is not only economic but 
educative. Riadh talked about a sort of 'educative radicalization' and mentioned how the search for religious answers through the Internet can lead to the adoption of the Salafi vision. Riadh has observed how globalization in general and the proliferation of satellites TVs have contributed in promoting understandings of the religion pertaining to the Gulf that he perceived as alien to the Tunisian context. These radical ideologies do not match the "Tunisian contemporary reality" for Riadh. He lamented the lack of a sound religious education which for him would be framed according to the national understanding of religion as characterized by the Tunisian tradition led by the Zitouna Mosque, the middle-way or Wasatiyyyah. Wasatiyyyah can be understood as "the principle of moderation and balance" (Kamali 2008, 7) and also relates, in the post 9/11 context to the way Islamic civilisation should related to other civilisations and avoidance of extremism (Kamali 2008). For the interviewees, Wasatiyyyah was alluded to as the specifically Tunisian experience of living Islam, implicitly suggesting that some practises or understandings of Islam are foreign to the country. Mouna, a young interviewee who adopted the niqab - the face-covering veil-for four years and evolved in Salafi circles before giving them up for a traditional hijab - a veil covering the hair, ears and neck but showing the full face- in 2015, also insisted on the need to "go back to our Tunisian roots”, criticizing influences from 'al Khalij' (The Gulf), whereby broadcasts and preaches from religious leaders in the Gulf States - such as Saudi Arabia, or Qatar - are promoting a version of Islam foreign to the local Tunisian practices of the faith.

From a prescriptive aspect, these observations give credit to Fahmi and Meddeb's recommendation to the government on the need to encourage imams to "compete with Salafi preachers to create a diverse marketplace of religious ideas" (Fahmi \& Meddeb 2015). Riadh also ended his explanation by stating that the Oulema 
and the Ministry of Religious Affairs had an important role to play in countering these radicalizing processes.

\section{Conclusion}

The motivations of foreign fighters can be quite heterogeneous, contributing to the demise of any typical profile of candidate to jihad. In the case of Tunisia, the volatile democratization process which also raised high and unmet expectations contributed to the acceleration of disaffection with regard to the political sphere. The opening of various channels following the redistribution of the political opportunity structure favoured not only Enhadha but also Salafi discourses in an era of extreme vulnerability. In this heavily securitized context, interviewees agreed on the necessity for civil society to monitor the behaviour of the government to avoid any return to the Ben Ali's era. So what are some of the grassroots perspectives on Tunisian terrorist fighters in this context?

Regarding motivations of Tunisian terrorist fighters, what is interesting to note is the extent to which interviewees tended to direct the discussion towards ideological issues rather than limit it to an issue of deprivation. Indeed, though the interviewees agreed on the speed of radicalization and the role of economic and social grievances as factors motivating to jihad, all of them quickly added that the economic and social perspectives are insufficient to fully comprehend the motivations of young fighters and that the ideological aspect is crucial. Consequently, they insisted, from a counterextremist perspective, on the concept of Wasatiyyyah and the need to direct efforts towards reconceptualising religions education and education in general.

The introduction of this article referred to Bentley, Lekalake and BuchananClarke observation that surveying grassroots perspectives can add "community-level perceptions that could be useful as counter-extremism policies are developed and 
refined" (Bentley, Lekalake and Buchanan-Clarke 2016, 1), especially as hybrid strategies including for instance deradicalization initiatives are being experienced or developed in states faced with the issue of returnees. At a time where Tunisian authorities have tended to rely primarily on repressive measures (Watanabe and Merz $2017,141)$, the insistence on education in general and religious education as well as the need to ground them in the Tunisian "Wasatiyyah" provide valuable insights for counter-extremism and counterterrorism.

\section{Acknowledgments}

The author is grateful to the Tunisian young citizens, students and civil society activists who agreed to the interviews.

\section{Notes}

1 Interview VIII, Riadh, Activist and Project Manager, "Mendoub El Mouwaten”, Skype Interview, 4 March 2017.

2 Interview VI, Maryem, Student, Skype Interview, 9 May 2015.

$3 \mathrm{Da}$ 'wa is a multidimensional concept that can take up different meanings. It stands for invitation in Arabic. Da'wa in the West is often understood as an invitation of non-Muslims to Islam and by extension, teaching and dispelling disinformation about Islam. However, in this context, da'wa corresponds to the case where « Militants submovements interpret dawah as calling Muslims back to the purer form of religion practiced by Muhammad and the early Muslim community », a return to what is considered the most authentic form of Islam (Oxford Dictionary of Islam ND).

4 Interview, Houda, Activist for the protection of Tunisian families, Geneva, 14 June 2014. 5 The name has been changed.

6 Interview, Saber, University graduate, Tunis, 6 August 2014.

\section{References}


Ajala, I., Paffenholz, T. \& al. (2013). Civil Society in Transition, Facing Current Challenges in Tunisia and Egypt. Cairo Issue Brief. Centre on Conflict, Development and Peacebuilding, The Graduate Institute, Geneva.

Al-Anani, K. (2012). Islamist Parties Post-Arab Spring. Mediterranean Politics, 17, 466-472.

Aliboni, R. (2011). The International Dimension of the Arab Spring. The International Spectator, 46, 5-9.

Argoubi, M. (2016). Tunisian Foreign Fighters to be dealt with under anti-terrorism law. Reuters, December 30. http://www.reuters.com/article/us-tunisia-securityidUSKBN14J1AL

Atwan, A. B. (2015). Islamic State: The Digital Caliphate. University of California Press.

Bakker, E., \& De Leede, S. (2015). European Female Jihadists in Syria: Exploring an Under-Researched Topic. International Center for Counter-Terrorism (ICCT)The Hague. April.

Baker E., Paulussen, C. and Entenmann, E. (2014). Returning Jihadist Foreign Fighters. Security \& Human Rights, 25, 11-32.

Behr, T., \& Siitonen, A. (2013). Building Bridges or Digging Trenches? Civil Society Engagement After the Arab Spring. Finish Institute of International Affairs. Working Paper 77, January.

Bentley T., Lekalake R. \& Buchanan-Clarke S. (2016). Threat of violent extremism from a 'grassroots' perspective: Evidence from North Africa. AfroBaromter Dispatch 100. 9 June.

http://afrobarometer.org/sites/default/files/publications/Dispatches/ab-r6dispatchno100-violent-extremism-nth-africa-en.pdf

Bunzel, C. (2015). From Paper State to Caliphate: The Ideology of the Islamic State. The Brookings Project on U.S. Relations with the Islamic World. Analysis Paper 19, March.

Carter, J. A., Shiraz, M., \& Neumann, R. (2014). Green Birds: Measuring Importance and Influence in Syrian Foreign Fighter Networks. International Centre for the Study of Radicalization. King's College, London. 
Fortier, Edwige A. (2015). Transition and Marginalization: Locating Spaces for Discursive Contestation in Post-Revolution Tunisia. Mediterranean Politics, 20, $142-160$

Geneva Academy of International Humanitarian Law and Human Rights. (2014). Foreign Fighters under International Law. Academy Briefing 7, October. Halaseh, R. (2012). Civil Society, Youth and the Arab Spring. In S. Calleya \& M. Wohlfeld, (Eds.) Change and Opportunities in the Emerging Mediterranean, Mediterranean Academy of Diplomatic Studies.

Hegghammer, T. (2010). The Rise of Muslim Foreign Fighters. International Security, $35,53-94$.

Human Rights Watch. (2015). Tunisia: Drop or Amend Security Bill. 13 May. https://www.hrw.org/news/2015/05/13/tunisia-drop-or-amend-security-bill International Commission of Jurists. (2015). Tunisia's Law on Counter-Terrorism in light of international law and standards. Position Paper. 6 August. https:/www.icj.org/wp-content/uploads/2015/08/Tunisia-CT-position-paperAdvocacy-PP-2015-ENG-REV.pdf

Jacinto, L. (2014). The Regretful Jihadists of the Islamic State. Foreign Policy Journal, 23 October. http://foreignpolicy.com/2014/10/23/the-regretful-jihadists-of-theislamic-state

Kamali, M. H. (2008). The Middle Grounds of Islamic Civilisation : The Qur'anic Principle of Wasatiyyah. IAIS Journal of Civilisation Studies, 1, 1-41.

Kerrou, M. (2017). De Bouazizi à Jemna, puissance et impuissance de la société civile. Huffington Post, 16 February. http://www.huffpostmaghreb.com/mohamedkerrou/de-bouazizi-a-jemna-puissance-et-impuissance-de-la-societecivile b 14792832.html

Klausen, J. (2015). “Tweeting the Jihad: Social Media Networks of Western Foreign Fighters in Syria and Iraq." Studies in Conflict \& Terrorism, 38, 1-22.

Laabidi, M. (2014). L'adoption de la nouvelle constitution tunisienne: le processus et les principals dipositions. $25^{\text {th }}$ session of the Human Rights Council. Discussion panel organized by the Permanent Mission of Tunisia in Geneva, African Union and Interparliamentary Union, Geneva, Switzerland. 5 March 2014. 
Macdonald, Geoffrey and Luke Waggoner. 2018. "Dashed Hopes and extremism in Tunisia”. Journal of Democracy 29(1):126-140.

Malka, H., \& Balboni, M. (2016). Tunisia, Radicalism Abroad and At Home. Centre for Strategic and International Studies, June.

http://foreignfighters.csis.org/tunisia/why-tunisia.html

Milton, D. (2016). Communication Breakdown. Unraveling the Islamic State's Media Efforts. West Point Combating Terrorism Center. October.

Norton, A. R. (1993). The Future of Civil Society in the Middle East. Middle East Journal, 47, 205-216.

OHCHR. (2015). Foreign Fighters: Urgent Measures Needed to Stop Flow from Tunisia-UN expert group warns. 10 July. Tunis/Geneva. http://www.ohchr.org/EN/NewsEvents/Pages/DisplayNews.aspx?NewsID=1622 3\&LangID $=\mathrm{E}$

Oxford Dictionary of Islam. ND. Entry: Dawah. http://www.oxfordislamicstudies.com/article/opr/t125/e511\#

Paffenholz, T. (2010). Civil Society and Peacebuilding: A Critical Assessment. Boulder, CO: Lynne Rienner.

Paffenholz, T., \& Spurk, C. 2006. "Civil Society, Civic Engagement and Peacebuilding” Social Development Papers, Conflict Prevention and Reconstruction paper 36, Washington, D.C.: World Bank.

Paffenholz, T. \& Spurk, C. 2010. A Comprehensive Analytical Framework. In Paffenholz, T. (Ed.). Civil Society and Peacebuilding: A Critical Assessment. Boulder: Lynne Rienner (pp. 65 -78).

Petré, C. (2015). The Jihad Factory. Foreign Policy. 20 March. http://foreignpolicy.com/2015/03/20/the-lynching-of-syed-sarifuddin-khan/

Sadowski, Y. (1993). The New Orientalism and the Democracy Debate. Middle East Report (MERIP), July-August: 14-21.

Sakbani, M. (2011). The Revolutions of the Arab Spring: Are Democracy, Development and Modernity at the Gates?. Contemporary Arab Affairs, 4, 127-147.

Saltman, E., \& Winter, C. (2014). The Changing Face of Modern Jihadism. Quilliam Foundation. 
Sayah, H. (2017). Tunisian Foreign Fighters: Between De-Territorialisation and ReTerritorialisation. In Not only Syria? The Phenomenon of Foreign Fighters in a Comparative Perspective, edited by Rekawek, Kacper, NATO Science for Peace and Security Series-E: Human and Societal Dynamics, 34, (pp. 98 -107).

Schmitter, P., \& 0'Donnel, G. (1986). Transitions from Authoritarian Rule. Tentative Conclusions about uncertain Democracies. John Hopkins University Press: Baltimore and London.

Security Council Counter-Terrorism Committee. ND. Foreign Terrorist Fighters. https://www.un.org/sc/ctc/focus-areas/foreign-terrorist-fighters/

Tunisian Centre for Research and Studies on Terrorism. (2016). Terrorism in Tunisia trough Judicial Files. Available in Arabic only:

لمركز التونسي للبحوث و الدر اسات حول الإرهاب .2016 ـالإر هاب في تونس من خلال الملفات القضائية .أكتوبر . https://inkyfada.com/wp-content/uploads/2016/12/etude-secret.pdf

UN Security Council. (2014). Resolution 2178 adopted by the Security Council at its 7272 nd meeting, on 24 September 2014. http://www.un.org/en/sc/ctc/docs/2015/SCR\%202178_2014_EN.pdf Vallianatos, S. (2013). Arab Civil Society at the Crossroads of Democratization: The Arab Spring Impact. Neighborhood Policy Paper.

Volpi, F. (2012). Explaining (and re-explaining) political change in the Middle East during the Arab Spring: trajectories of democratization and of authoritarianism in the Maghreb. Democratization, 1, 1-22.

Watanabe, L. \& Merz, F. (2017). Tunisia's Jihadi Problem and How to Deal with It. Middle East Policy, XXIV, 136-147.

Weyland, K. (2012). The Arab Spring: Why the Surprising Similarities with the Revolutionary Wave of 1848?. Perspectives on Politics, 101, 917-934.

World Value Survey. 2013. World Values Survey Wave 6. 2010-2014 Official Aggregate v.20150418. http://www.worldvaluessurvey.org/WVSDocumentationWV6.jsp

Zelin, A. (2015). Tunisia's Fragile Democratic Transition. The Washington Institute for Near East Policy. Testimony submitted to the House Committee on Foreign Affairs, Subcommittee on the Middle East and North Africa. July 14. 
https://www.washingtoninstitute.org/uploads/Documents/testimony/ZelinTestim ony20150714.pdf

Zisenwine, D. (2016). Tunisia's Fragile Post-Revolutionary Order. Middle East

Quarterly, 23, 1-12. 